Article

\title{
The Study of Plasticized Solid Polymer Blend Electrolytes Based on Natural Polymers and Their Application for Energy Storage EDLC Devices
}

\author{
Elham M.A. Dannoun ${ }^{1}$, Shujahadeen B. Aziz ${ }^{2,3, *(\mathbb{D})}$, Mohamad A. Brza ${ }^{4}$, Muaffaq M. Nofal ${ }^{5}(\mathbb{D}$, \\ Ahmad S.F.M. Asnawi ${ }^{6}$, Yuhanees M. Yusof ${ }^{6}{ }^{(D)}$, Shakhawan Al-Zangana ${ }^{7}$ (D), \\ Muhamad H. Hamsan ${ }^{8}$, Mohd F. Z. Kadir ${ }^{9}$ and Haw J. Woo ${ }^{10}{ }^{D}$ \\ 1 Associate Director of General Science Department, Woman Campus, Prince Sultan University, \\ P. O. Box 66833, Riyadh 11586, Saudi Arabia; elhamdannoun1977@gmail.com \\ 2 Hameed Majid Advanced Polymeric Materials Research Lab., Physics, College of Science, University of \\ Sulaimani, Qlyasan Street, Sulaimani 46001, Kurdistan Regional Government, Iraq \\ 3 Department of Civil engineering, College of Engineering, Komar University of Science and Technology, \\ Sulaimani 46001, Kurdistan Regional Government, Iraq \\ 4 Manufacturing and Materials Engineering Department, Faculty of Engineering, International Islamic \\ University of Malaysia, Kuala Lumpur 50603, Gombak, Malaysia; mohamad.brza@gmail.com \\ 5 Department of Mathematics and General Sciences, Prince Sultan University, P. O. Box 66833, \\ Riyadh 11586, Saudi Arabia; muaffaqnofal@gmail.com \\ 6 Chemical Engineering Section, Universiti Kuala Lumpur, Malaysian Institute of Chemical \& Bioengineering \\ Technology (UniKL MICET), Alor Gajah 78000, Malacca, Malaysia; \\ asyafiq.asnawi@s.unikl.edu.my (A.S.F.M.A.); yuhanees@unikl.edu.my (Y.M.Y.) \\ 7 Department of Physics, College of Education, University of Garmian, Kalar 46021, Iraq; \\ shakhawan.al-zangana@garmian.edu.krd \\ 8 Institute for Advanced Studies, University of Malaya, Kuala Lumpur 50603, Malaysia; \\ hafizhamsan93@gmail.com \\ 9 Centre for Foundation Studies in Science, University of Malaya, Kuala Lumpur 50603, Malaysia; \\ mfzkadir@um.edu.my \\ 10 Centre for Ionics, Department of Physics, Faculty of Science, University of Malaya, \\ Kuala Lumpur 50603, Malaysia; woohj@um.edu.my \\ * Correspondence: shujahadeenaziz@gmail.com
}

Received: 8 October 2020; Accepted: 27 October 2020; Published: 29 October 2020

\begin{abstract}
In this work, plasticized magnesium ion-conducting polymer blend electrolytes based on chitosan:methylcellulose (CS:MC) were prepared using a solution cast technique. Magnesium acetate $\left[\mathrm{Mg}\left(\mathrm{CH}_{3} \mathrm{COO}\right)_{2}\right]$ was used as a source of the ions. Nickel metal-complex [Ni(II)-complex)] was employed to expand the amorphous phase. For the ions dissociation enhancement, glycerol plasticizer was also engaged. Incorporating $42 \mathrm{wt} \%$ of the glycerol into the electrolyte system has been shown to improve the conductivity to $1.02 \times 10^{-4} \mathrm{~S} \mathrm{~cm}^{-1}$. X-ray diffraction (XRD) analysis showed that the electrolyte with the highest conductivity has a minimum crystallinity degree. The ionic transference number was estimated to be more than the electronic transference number. It is concluded that in CS:MC: $\mathrm{Mg}\left(\mathrm{CH}_{3} \mathrm{COO}\right)_{2}: \mathrm{Ni}(\mathrm{II})$-complex:glycerol, ions are the primary charge carriers. Results from linear sweep voltammetry (LSV) showed electrochemical stability to be $2.48 \mathrm{~V}$. An electric double-layer capacitor (EDLC) based on activated carbon electrode and a prepared solid polymer electrolyte was constructed. The EDLC cell was then analyzed by cyclic voltammetry (CV) and galvanostatic charge-discharge methods. The CV test disclosed rectangular shapes with slight distortion, and there was no appearance of any redox currents on both anodic and cathodic parts, signifying a typical behavior of EDLC. The EDLC cell indicated a good cyclability of about (95\%) for throughout of 200 cycles with a specific capacitance of $47.4 \mathrm{~F} / \mathrm{g}$.
\end{abstract}


Keywords: polymer blend; magnesium salt; electrochemical impedance spectroscopy; cyclic voltammetry study; electrochemical double-layer capacitor

\section{Introduction}

The new characteristics of nano-sized metal particles $(\mathrm{Fe}, \mathrm{Ce}, \mathrm{Cu}, \mathrm{Zn}$ and $\mathrm{Ni}$ ) are nowadays studied because of their large surface areas and electronic structure. Metal complexes have emerged as an area of great current interest motivated by possible energy technology applications, electronics, optics, chemical catalysis and magnetics [1-3]. Their properties may be adjusted via control of the metal particle size, shape and organization. Furthermore, metal nano-particles also depend on the microenvironment's chemical nature surrounding the particle [4]. As stated in the literature [5], metal complexes reduce the polymer electrolyte energy bandgap. This benefit is useful in energy device applications. Based on our previous work [6], the incorporation of $\mathrm{Zn}$ metal complex ( $\mathrm{Zn}$ (II)-complex) has enhanced the amorphousness of chitosan- $\mathrm{NH}_{4} \mathrm{~F}$-glycerol electrolyte. Furthermore, the authors used the electrolyte in the electrochemical double-layer capacitor (EDLC) device application, and they indicated that the $\mathrm{Ni}(\mathrm{II})$-complex improved the EDLC device performance. Brza et al. [5] documented that a $\mathrm{Cu}$ (II)-complex in polyvinyl alcohol (PVA) greatly enhanced the amorphous phase. This condition is advantageous to electrolyte application because ions are transported easily in the amorphous region, thus improving the ionic conductivity [3].

Biopolymers are natural polymers where various kinds of source can be used. Biopolymers usually are inexpensive, naturally abundant, have high compatibility with solvents and are very stable in forming a film $[7,8]$. A solid polymer electrolyte is considered as a suitable candidate for energy device applications, due to the good electrochemical and thermal stability, in addition to high ionic conductivity at ambient temperature [9-12]. Moreover, the good flexibility of this type of electrolyte enhances the arrangement in various geometries to create optimal electrode/electrolyte contact, which is crucial for energy devices $[13,14]$. Literature revealed that energy devices based on a polymer electrolyte have been widely addressed and researchers have put great effort into this with particular attention given to batteries [9-16] and supercapacitors (SCs) [17-24].

Many works on polymer electrolyte (PE) have reported that ionic conductivity ranged from $10^{-5}$ to $10^{-3} \mathrm{~S} / \mathrm{cm}$, where biopolymers were used as host polymers, such as cellulose, starch, dextran, chitin, gelatin, chitosan (CS) and carrageenan [25-27]. Chitosan is widely studied in energy device technologies and environmental and health approaches [28]. Ions from salt can be transported through the oxygen-containing functional groups present in the CS structure, such as hydroxyl $(\mathrm{OH})$, glycosidic linkage, anhydroglucose ring oxygen and amine [29]. The inclusion of organic materials like methyl chloride or dimethyl sulfate to alkali-based cellulose produces a tailored biopolymer called methylcellulose (MC) with a 1,4 glycosidic bond [30].

For many decades, batteries have been the primary energy sources used in various electrical appliances and vehicles. The preparation of batteries is much more expensive and complicated than the alternative EDLC. Electrodes used in an EDLC are usually carbon-based, where ions from salt undergo a non-Faradaic process for storing energy [31]. Various types of altered carbons, such as graphite [32], carbon aerogel [33], carbon nanotubes [34] and activated carbon [35], have been used as the active material in EDLCs. Activated carbon has been extensively studied in the electrodes field due to its extra surface area $\left(\sim 2500 \mathrm{~m}^{2} / \mathrm{g}\right)$, good chemical stability and excellent electronic conductivity [36]. The EDLC is preferable to other SCs due to its high power density, high durability and better thermal stability, also being cheap with an uncomplicated methodology to make EDLC devices [37-39].

In PE, it is noticeable that few works reported on magnesium salt-based PEs compared to $\mathrm{Li}^{+}$ or $\mathrm{Na}^{+}$or $\mathrm{H}^{+}$[40]. Low equivalence weight, low price, high safety and high reduction potential compared to lithium are why magnesium salt-based PEs can be an excellent substitute for other types of electrolyte [41]. The work of Polu et al. [42] showed that the inclusion of magnesium salt enhanced 
the ionic conductivity and flexibility of PVA as the glass transition temperature $\left(T_{\mathrm{g}}\right)$ of the polymer decreased. Hassan et al. [43] concluded that ionic diffusivity, number density and mobility had been improved by incorporating $35 \mathrm{wt} \%$ magnesium sulfate $\left(\mathrm{MgSO}_{4}\right)$. In this work, CS is blended with MC to produce a more stable polymer host. Magnesium acetate $\mathrm{Mg}\left(\mathrm{CH}_{3} \mathrm{COO}\right)_{2}$ and glycerol are used as ionic sources and plasticizers, respectively. The effect of the addition of a Ni metal complex (Ni(II)-complex) on PE electrical and structural properties has also been investigated. The highest conducting electrolyte is used in the fabrication of the EDLC device.

\section{Materials and Methods}

\subsection{Materials and Sample Preparation}

All chemicals were obtained from Sigma-Aldrich (St. Louis, MO, USA) and used with no extra purification. Two primary raw materials were used to fabricate glycerolized CS:MC: $\mathrm{Mg}\left(\mathrm{CH}_{3} \mathrm{COO}\right)_{2}: \mathrm{Ni}(\mathrm{II})$-complex blend electrolyte systems, $\mathrm{CS}$ and MC with the average molecular weights of 310,000-375,000 g/moL and 10,000-220,000 g/mol, respectively. Other raw materials were magnesium acetate $\left(\mathrm{Mg}\left(\mathrm{CH}_{3} \mathrm{COO}\right)_{2}\right)$, acetic acid $\left(\mathrm{CH}_{3} \mathrm{COOH}\right), \mathrm{Ni}(\mathrm{II})$-complex and glycerol $\left(\mathrm{C}_{3} \mathrm{H}_{8} \mathrm{O}_{3}\right)$, involved in the solution-casting technique. The blend's fabrication contained a dissolution of $0.5 \mathrm{~g}$ of CS in $30 \mathrm{~mL}$ of the $1 \%$ acetic acid solution, which was then stirred for several hours at ambient temperature. The MC solution was prepared by dissolving and stirring $1 \mathrm{~g}$ of MC in 80 $\mathrm{mL}$ distilled water for several hours by a magnetic stirrer until a homogeneous solution was achieved at room temperature. The two different solutions (i.e., $\mathrm{CS}$ and $\mathrm{MC}$ ) were combined and continuously stirred with a magnetic stirrer to fabricate CS:MC polymer blends. Next, $40 \mathrm{wt} \%$ of $\mathrm{Mg}\left(\mathrm{CH}_{3} \mathrm{COO}\right)_{2}$ salt was incorporated and stirred into the CS:MC blended solutions until a homogenous solution was achieved. Additionally, $10 \mathrm{~mL}$ of $\mathrm{Ni}(\mathrm{II})$-complex of a fixed amount was added to the electrolyte systems. Finally, glycerol separately with different amounts was added to the electrolyte systems. Then, the CS:MC: $\mathrm{Mg}\left(\mathrm{CH}_{3} \mathrm{COO}\right)_{2}: \mathrm{Ni}(\mathrm{II})$-complex systems were coded as CSMCMNG1, CSMCMNG2 and CSMCMNG3 with the addition of 14, 28 and $42 \mathrm{wt} \%$ of glycerol, respectively. Each fabricated solution was then poured into clean and dry labeled Petri dishes and left to evaporate at ambient temperature. Table 1 displays the composition of the electrolyte films.

Table 1. The designation and composition for the glycerol plasticized of chitosan (CS):methylcellulose (MC): $\mathrm{Mg}\left(\mathrm{CH}_{3} \mathrm{COO}\right)_{2}$ : $\mathrm{Ni}(\mathrm{II})$-complex systems.

\begin{tabular}{ccccccc}
\hline $\begin{array}{c}\text { Sample } \\
\text { Designation }\end{array}$ & $\mathbf{C S}(\mathbf{g})$ & $\mathbf{M C}(\mathbf{g})$ & $\begin{array}{c}\mathbf{M g}\left(\mathrm{CH}_{\mathbf{3}} \mathrm{COO}\right)_{2} \\
\mathbf{( g )}\end{array}$ & $\begin{array}{c}\mathbf{N i}(\mathrm{II})-C o m p l e x \\
(\mathbf{m L})\end{array}$ & Glycerol (g) & Glycerol (wt $\%)$ \\
\hline CSMCMNG1 & 0.5 & 0.5 & 0.666 & 10 & 0.271 & 14 \\
CSMCMNG2 & 0.5 & 0.5 & 0.666 & 10 & 0.647 & 28 \\
CSMCMNG3 & 0.5 & 0.5 & 0.666 & 10 & 1.206 & 42 \\
\hline
\end{tabular}

\subsection{X-ray Diffraction}

For X-ray diffraction (XRD) experiments, a Siemens D5000 X-ray diffractometer (Bruker AXS $\mathrm{GmbH}$, Berlin, Germany) was applied under a certain electric operating condition (40 kV and $40 \mathrm{~mA})$. Monochromatic $\mathrm{CuK} \alpha$ radiation (1.5406 $⿱$ ) $)$ at glancing angles between $10^{\circ}$ and $80^{\circ}$ with a step size of $0.1^{\circ}$ was scanned over the films. To obtain the crystallinity degree, it is crucial to deconvolute each film XRD pattern to determine the areas of the amorphous and crystalline peaks [44]. The degree of crystallinity $\left(X_{c}\right)$ was calculated with Equation (1) [45]:

$$
\mathrm{Xc}=\frac{A_{\mathrm{C}}}{A_{T}} \times 100 \%
$$

where $A_{C}$ and $A_{T}$ refer to the crystalline peaks area and the total area of crystalline and amorphous peaks, respectively. 


\subsection{Electrical Impedance Spectroscopy (EIS)}

Electrical impedance spectroscopy (EIS) is an appropriate technique for learning a material's electrical property, and has been used in electrochemical energy storage devices [46]. It gives vital evidence about the electrical properties at the interfacial space among electronically conducting electrodes and electrolytes. Before impedance measurements, the electrolyte films were cut into small discs of $2 \mathrm{~cm}$ in diameter and then positioned between two stainless steel electrodes via spring pressure. The impedance measurements were performed via HIOKI 3531 Z Hi-tester (Hioki, Nagano, Japan) with a computer in the frequency range between $50 \mathrm{~Hz}$ and $5000 \mathrm{kHz}$ at room temperature. Software extracted both real $\left(Z^{\prime}\right)$ and imaginary $\left(Z^{\prime \prime}\right)$ parts of the impedance spectra of the EIS plots. From the plot's intersection with the real axis, the bulk resistance $\left(R_{b}\right)$ was obtained. From the $R_{b}$, the conductivity of the films was measured using Equation (2) [46]:

$$
\sigma_{d c}=\left(\frac{1}{R_{b}}\right) \times\left(\frac{t}{A}\right)
$$

where $t$ is the thickness of the film and $A$ is the area of the electrode.

\subsection{Electrochemical Characterization}

\subsubsection{Linear Sweep Voltammetry (LSV) and Transference Number Measurements (TNMs)}

Linear sweep voltammetry (LSV) was conducted to test the cells' electrochemical stability, using Digi-IVY DY2300 potentiostat (Neware, Shenzhen, China) at a scan rate of $20 \mathrm{mV} / \mathrm{s}$. Transference number measurements (TNMs) were performed at room temperature using a direct current (DC) polarization method by tracking the polarization current as a function of time. The cell was polarized at $0.2 \mathrm{~V}$ using a V\&A Instrument DP3003 digital DC power supply (V \& A Instrument, Shanghai, China). For both TNM and LSV, the cell consisted of the highest conducting polymer blend electrolyte (CSMCMNG3) sandwiched by two stainless steel electrodes (SSE). Ionic transference number $\left(t_{i}\right)$ can be determined if the initial $\left(I_{i}\right)$ and steady-state $\left(I_{S S}\right)$ currents are known using the following Equation (3):

$$
t_{i}=\frac{I_{i}-I_{s S}}{I_{i}}
$$

The following Equation (4) can obtain electron transference number $\left(t_{e}\right)$ :

$$
t_{e}=1-t_{i}
$$

\subsubsection{Fabrication and Characterization of Electric Double-Layer Capacitor (EDLC)}

The carbon electrodes preparation was the initial step for the EDLC preparation. Activated carbon of $3.25 \mathrm{~g}$ was dry-mixed with $0.25 \mathrm{~g}$ carbon black powder, using a planetary ball miller (XQM-0.4) at a rotational speed of $500 \mathrm{r} / \mathrm{min}$ for $15 \mathrm{~min}$. Moreover, $0.50 \mathrm{~g}$ polyvinylidene fluoride (PVdF) was dissolved in $15 \mathrm{~mL} \mathrm{~N}$-methyl pyrrolidone (NMP) at room temperature. The activated carbon-carbon black powders were then dissolved for $90 \mathrm{~min}$ in the PVdF-NMP solution. The obtained homogeneous solution was then coated on aluminum foil and dried in an oven at $60^{\circ} \mathrm{C}$ for $120 \mathrm{~min}$. Lastly, the dried electrodes (thickness $=0.01 \mathrm{~cm}$ ) were stored in a desiccator filled with silica gel to remove extra moisture. The highest conducting electrolyte cut into a circle shape with an area of $2.01 \mathrm{~cm}^{2}$ was sandwiched between two carbon electrodes prepared in the initial step and packed in CR2032 coin cells. The galvanostatic charge-discharge characteristics of the EDLC were conducted using a NEWARE battery cycler (current density $=0.75 \mathrm{~mA} / \mathrm{cm}^{2}$ ). Several parameters of the EDLC can be obtained using the following Equations (5)-(9):

$$
C_{c d}=\frac{i}{g m}
$$




$$
\begin{gathered}
E S R=\frac{V_{d}}{i} \\
E=\frac{C_{s} V^{2}}{2} \\
P=\frac{V^{2}}{4 m(E S R)} \\
\text { Efficiency }=\frac{t_{\text {dis }}}{t_{\text {cha }}}
\end{gathered}
$$

where $i$ is the applied current, which was $1.5 \mathrm{~mA}, g$ is the slope of the discharge part, $m$ is the mass of active material, $V_{d}$ is the voltage drop before the discharge process initiates and $V$ is the voltage applied $(0.9 \mathrm{~V}) . t_{d}$ and $t_{c}$ are the time taken for one complete discharging and charging, respectively. A Digi-IVY DY2300 Potentiostat was used to perform cyclic voltammetry (CV) analysis of the EDLC at different scan rates (from 10 to $100 \mathrm{mV} / \mathrm{s}$ ). The potential range was from 0 to $0.9 \mathrm{~V}$. Specific capacitance $\left(C_{c v}\right)$ can be obtained from CV using the following Equation (10):

$$
C_{c v}=\int_{V_{i}}^{V_{f}} \frac{I(V) d V}{2 m h\left(V_{f}-V_{i}\right)}
$$

where $I(V) d V$ stands for the CV's area determined using the Origin 9.0 software through the integration function. $m$ and $h$ are the mass of active material and scan rate, respectively. $V_{i}$ and $V_{f}$ in this work are $0 \mathrm{~V}$ and $0.9 \mathrm{~V}$, respectively.

\section{Results and Discussion}

\subsection{X-ray Diffraction (XRD) Study}

Figure 1 shows the deconvoluted XRD spectra for the electrolyte films. The XRD spectrum of pure CS film is pointed out in Figure 1a. It is accepted that the crystalline peaks for pure CS are recorded at $2 \theta=15.1,17.7$ and $20.9^{\circ}$ as a consequence of inter- and intra-hydrogen bonding between the functional groups of individual monomers and the chains [44,47]. The MC semi-crystalline nature is an inherent structural feature that enables X-ray examinations to be performed through the MC's influence on the biopolymer matrix [48]. It has been reported that there exists only one hollow at $2 \theta=19^{\circ}-21^{\circ}$ for $\mathrm{MC}$ material, which originates from the intermolecular hydrogen bonding together with a short-distance order in the MC polymer chains [49-51]. The interesting point is that a broad peak at a diffraction angle $2 \theta$ of $8.03^{\circ}$ is recognized to relate to the presence of tri-methyl glucose repeating unit within the MC [48].

It should be noted that two distinct concave peaks can be seen from the XRD pattern of the CS:MC system (see Figure 1b). The broad hollows can verify that the CS:MC blend indicates an entirely amorphous structure $[52,53]$. Figure $1 c, d$ shows the XRD pattern obtained for the desired blend electrolyte samples. Interestingly, with the addition of $14 \mathrm{wt} \%$ of glycerol plasticizer into CS: $\mathrm{MC}: \mathrm{Mg}\left(\mathrm{CH}_{3} \mathrm{COO}\right)_{2}: \mathrm{Ni}(\mathrm{II})$-complex matrix, the crystalline peaks and hollow intensity were lowered as can be seen in Figure 1c. This can be considered as evidence of decreasing the crystalline region in the CS matrix [44]. It is obvious from Figure $1 \mathrm{~d}$ that adding $42 \mathrm{wt} \%$ of plasticizer to CS:MC mixture can result in more broadening of the hollow and noticeably decreasing the crystalline diffraction peaks. Peak broadening and lowering in intensity reveal that the amorphous region within the blended polymer is dominant. Another advantage of XRD analysis is that it can anticipate the electrolyte's conductivity trend [54].

The $X_{c}$ for each system was calculated using Equation (1). It is remarkable that the $X_{c}$ is decreased upon the insertion of MC content (see Table 2). The deconvoluted XRD spectra of plasticized CS:MC electrolyte is shown in Figure 1c,d. It is interesting to note that the intensity of the XRD peaks is considerably reduced. Based on former research, salt can terminate the polymer chain's hydrogen 
bonding because of electrostatic reactions created among the salt cations and polymer functional groups [55]. The amorphous structure growth might be related to the crystalline phase interruption in the polymer [56]. Compared to the pure blend systems, the plasticized system's degree of crystallinity is very significantly diminished (see Table 2). Plasticizers are a famous approach to raising the number of free ions and decreasing the crystallinity [57].

Table 2. The degree of crystallinity using deconvoluted X-ray diffraction (XRD) examination.

\begin{tabular}{cc}
\hline Electrolyte & Degree of Crystallinity (\%) \\
\hline Pure CS & 15.97 \\
CS: MC & 13.93 \\
CSMCMNG1 & 11.21 \\
CSMCMNG3 & 2.08 \\
\hline
\end{tabular}
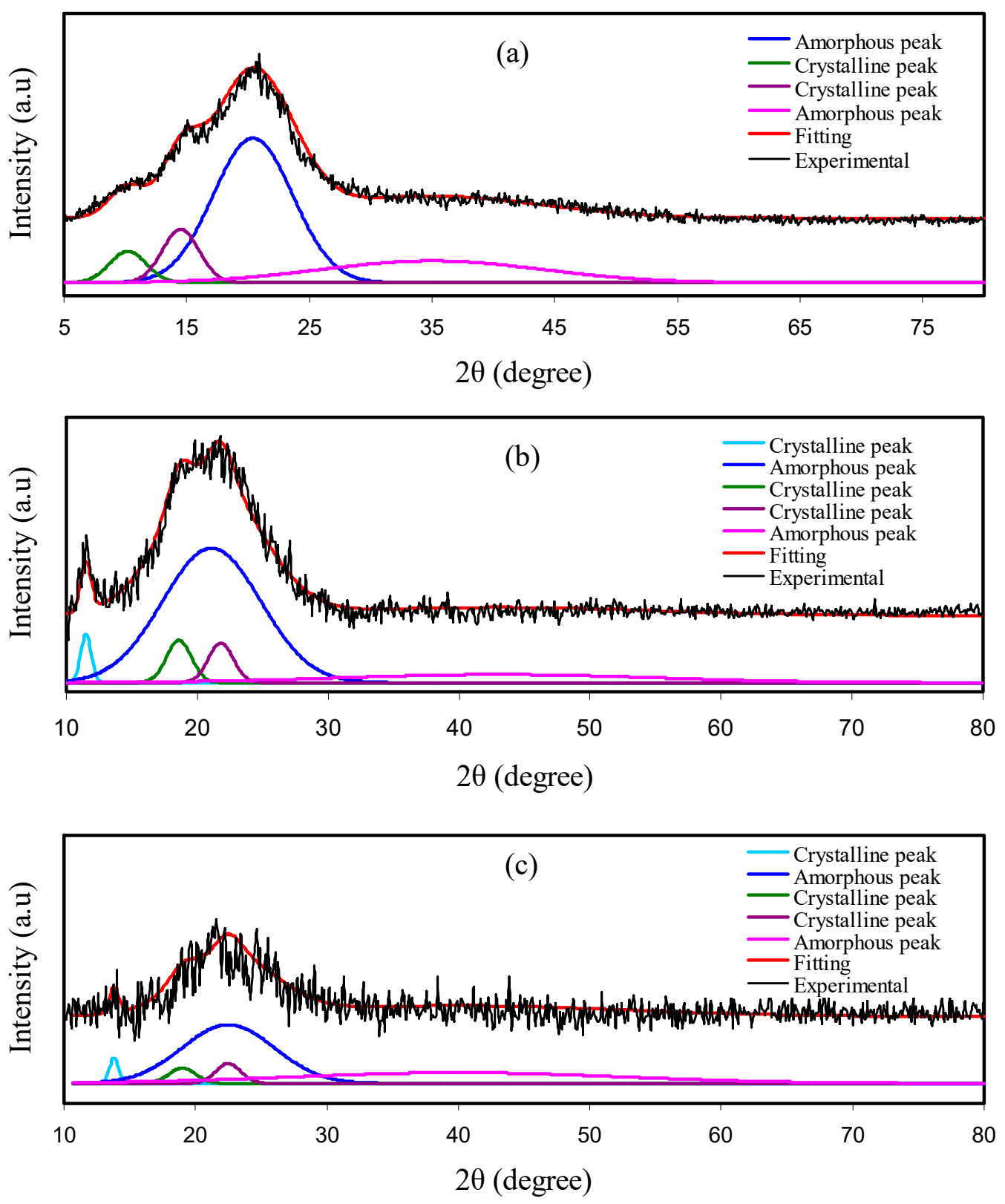

Figure 1. Cont. 


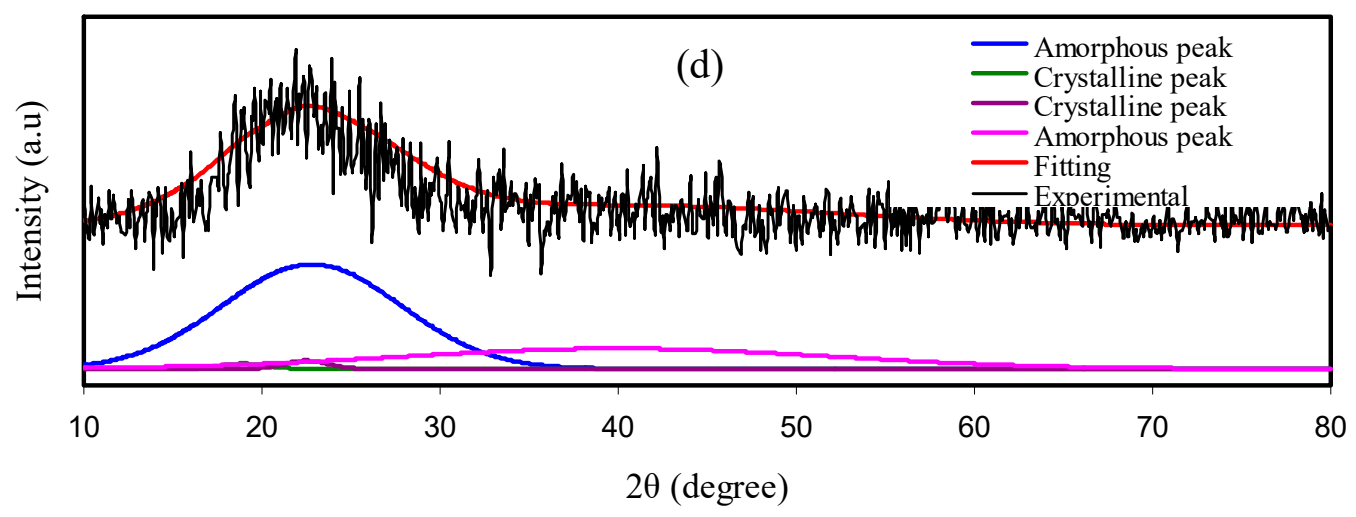

Figure 1. XRD spectra for (a) pure CS, (b) CS:MC, (c) CSMCMNG1 and (d) CSMCMNG3 electrolyte films.

\subsection{Impedance Analysis}

Using electrochemical impedance spectroscopy (EIS), the electrochemical and ion transference behaviors of ionic materials, such as electrodes and PEs, can be examined, effectively [53,58-61]. Here, EIS was used to analyze the electrolyte films shown in Figure 2a-c. For CSMCMNG1 and CSMCMNG2 systems shown in Figure 2a,b, a semicircle at the high-frequency region has resulted from the bulk effect of the electrolytes, and a tail at low frequencies can be noted. Due to the creation of EDLC, the tail at the low frequencies occurs through the free charges' accumulation at the electrode and electrolyte interface [62]. The CSMCMNG3 system only displayed the spike or tail (see Figure 2c).

As a straightforward method for EIS examination, the electrical equivalent circuit (EEC) method is used, which provides the entire image of the electrolyte system [63]. In terms of the EEC, the Nyquist plot for the systems was deduced. It comprises bulk resistance $\left(R_{b}\right)$ for the electrolyte system carriers and two constant phase elements (CPE), as shown in the Figure 2 inset. The high-frequency region displays the parallel connection of $R_{b}$ and constant phase element, while the low-frequency region indicates only the constant phase element, meaning that the EDLC formed between electrode and electrolyte. In EEC, the constant phase elements are used more generally than the ideal capacitor in the real system. $Z_{C P E}$ impedance can be written as $[53,64,65]$ :

$$
Z_{C P E}=\frac{1}{C \omega^{p}}\left[\cos \left(\frac{\pi p}{2}\right)-i \sin \left(\frac{\pi p}{2}\right)\right]
$$

where $C$ stands for the constant phase element's capacitance, $\omega$ refers to the angular frequency and $p$ is linked from the vertical axis to the EIS plot's departure.

Here, the real $\left(Z_{r}\right)$ and imaginary $\left(Z_{i}\right)$ parts of complex impedance $\left(Z^{*}\right)$ correlated with the EEC (inset of Figure $2 a, b$ ) are indicated as [66]:

$$
\begin{aligned}
& Z_{r}=\frac{R_{b} C_{1} \omega^{p 1} \cos \left(\frac{\pi p_{1}}{2}\right)+R_{b}}{2 R_{b} C_{1} \omega^{p 1} \cos \left(\frac{\pi p_{1}}{2}\right)+R_{b}{ }^{2} C_{1}{ }^{2} \omega^{2 p 1}+1}+\frac{\cos \left(\frac{\pi p_{2}}{2}\right)}{C_{2} \omega^{p 2}} \\
& Z_{i}=\frac{R_{b} C_{1} \omega^{p 1} \sin \left(\frac{\pi p_{1}}{2}\right)}{2 R_{b} C_{1} \omega^{p 1} \cos \left(\frac{\pi p_{1}}{2}\right)+R_{b}{ }^{2} C_{1}{ }^{2} \omega^{2 P 1}+1}+\frac{\sin \left(\frac{\pi p_{2}}{2}\right)}{C_{2} \omega^{p 2}}
\end{aligned}
$$

where $C_{1}$ refers to the bulk constant phase element capacitance and $C_{2}$ refers to the constant phase element capacitance at the electrode and electrolyte interface.

Here, the $Z_{r}$ and $Z_{i}$ parts of $Z^{*}$ associated with the EEC (inset of Figure 2c) are expressed as [66,67]:

$$
Z_{r}=R+\frac{\cos \left(\frac{\pi p_{2}}{2}\right)}{C_{2} \omega^{p 2}}
$$




$$
Z_{i}=\frac{\sin \left(\frac{\pi p_{2}}{2}\right)}{C_{2} \omega^{p 2}}
$$

Table 3 shows the fitting parameters of the EEC. $R_{b}$ is obtained by the interception between the real axis and the spike. It is evident that, upon the addition of glycerol, the semicircle at the high-frequency region was absent (see Figure 2c) due to the complete transport of ions toward the electrodes. To calculate the ionic conductivity of the electrolytes, Equation (2) was used. In the present work, the obtained maximum ionic conductivity is $1.02 \times 10^{-4} \mathrm{~S} \mathrm{~cm}^{-1}$ when $42 \mathrm{wt} \%$ glycerol was added at room temperature, as listed in Table $4 . R_{b}$ decreased as the glycerol amount increased to $42 \mathrm{wt} \%$ due to increased charge carriers; thus, ion conductivity increases.
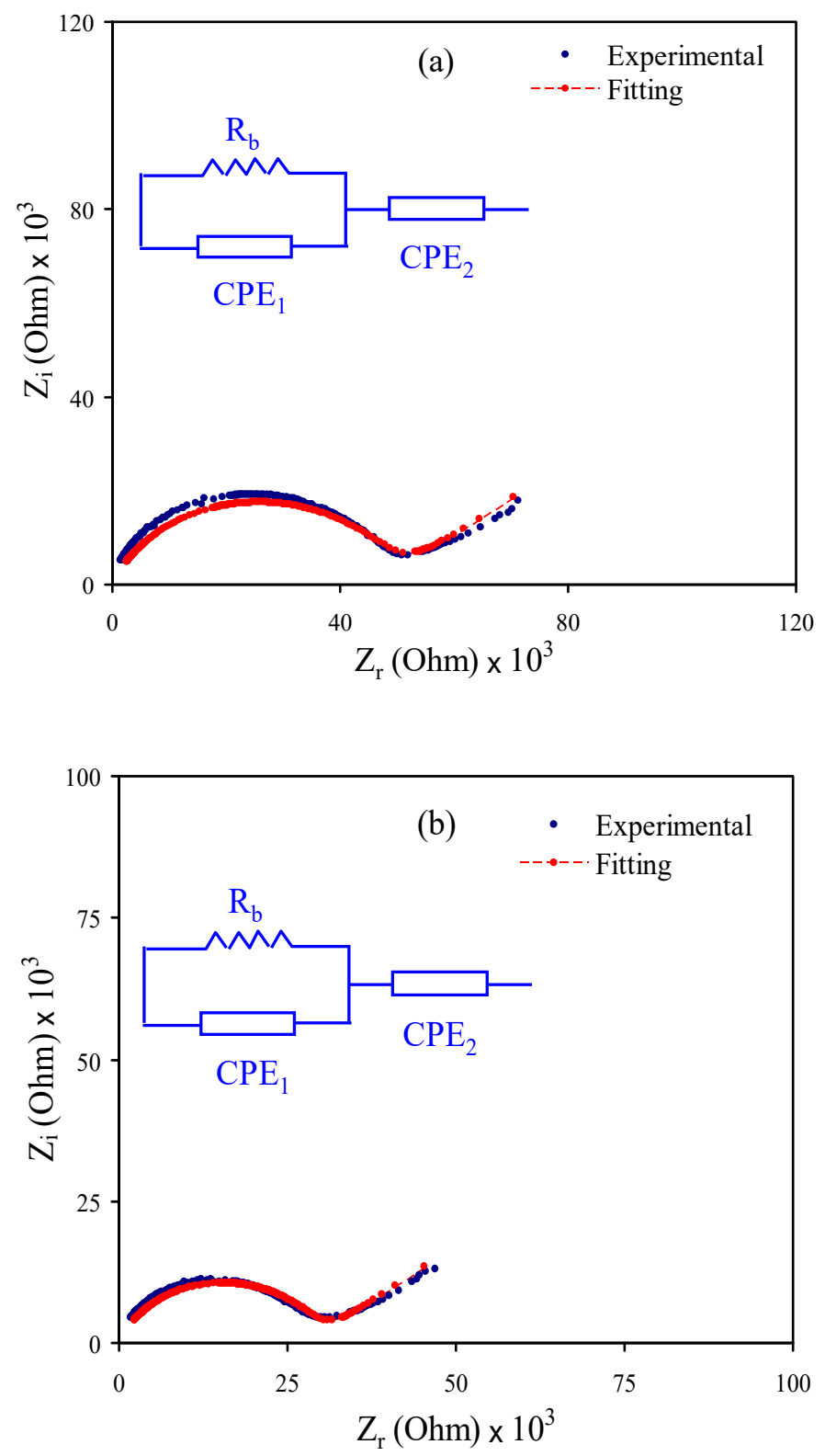

Figure 2. Cont. 


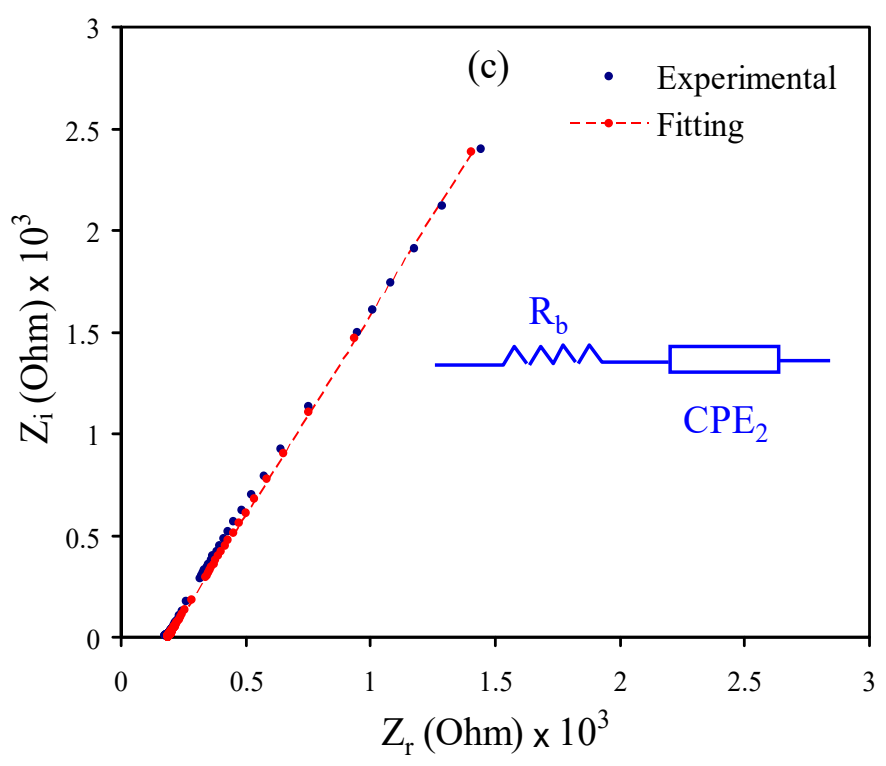

Figure 2. Electrochemical impedance spectroscopy (EIS) plots for (a) CSMCMNG1, (b) CSMCMNG2 and (c) CSMCMNG3 electrolyte films.

Table 3. The electrical equivalent circuit (EEC) fitting parameters for plasticized electrolyte systems at room temperature.

\begin{tabular}{ccccc}
\hline Sample & $\mathbf{K}_{\mathbf{1}}\left(\mathbf{F}^{-\mathbf{1}}\right)$ & $\mathbf{K}_{\mathbf{2}}\left(\mathbf{F}^{-\mathbf{1}}\right)$ & $\mathbf{C}_{\mathbf{1}} \mathbf{( F )}$ & $\mathbf{C}_{\mathbf{2}} \mathbf{( F )}$ \\
\hline CSMCMNG1 & $9.6 \times 10^{8}$ & $3.65 \times 10^{5}$ & $1.04 \times 10^{-9}$ & $2.74 \times 10^{-6}$ \\
CSMCMNG2 & $8.6 \times 10^{8}$ & $2.65 \times 10^{5}$ & $1.16 \times 10^{-9}$ & $3.77 \times 10^{-6}$ \\
CSMCMNG3 & - & $1.0 \times 10^{5}$ & - & $1.0 \times 10^{-5}$ \\
\hline
\end{tabular}

Table 4. DC conductivity for plasticized electrolyte systems at room temperature.

\begin{tabular}{ccc}
\hline Designation & $\mathbf{R}_{\mathbf{b}} \mathbf{( O h m )}$ & Conductivity $\left.\mathbf{( S ~ c m}^{\mathbf{- 1}}\right)$ \\
\hline CSMCMNG1 & $4.97 \times 10^{4}$ & $2.31 \times 10^{-7}$ \\
CSMCMNG2 & $2.96 \times 10^{4}$ & $4.42 \times 10^{-7}$ \\
CSMCMNG3 & 190 & $1.02 \times 10^{-4}$ \\
\hline
\end{tabular}

\subsection{Electrochemical Studies}

\subsubsection{Transference Number Measurement (TNM) Study}

Both ions and electrons carry electric charges in a PE system. For EDLC applications, it is essential to use a PE with high $t_{i}$ rather than high $t_{e}$. The energy storage process of the EDLC is through adsorption/desorption of ions at the surface of carbon electrodes. TNM analysis has been conducted where the PE is subjected to a working voltage of $0.8 \mathrm{~V}$. Figure 3 shows the polarization plot for the highest conducting electrolyte at room temperature. As the voltage is applied, both ions and electrons move towards the electrodes, producing a high $I_{i}$ of $2.8 \mu \mathrm{A}$. As time goes by, ions are blocked at the surface of the stainless steel (SS) electrodes. This situation reduces the current flow. Stable current $(0.1 \mu \mathrm{A})$ can be observed beyond $10 \mathrm{~s}$; it means that the PE is now completely polarized and at this point only electrons can flow through the SS electrodes. This phenomenon is the typical behavior of an ionic conductor accompanying electron transfer [68]. From Equations (3) and (4), $t_{i}$ and $t_{e}$ are identified as 0.964 and 0.036 , respectively. $t_{i}$ is found to be more than the reported value of 0.95 for $\mathrm{Mg}\left(\mathrm{CH}_{3} \mathrm{COO}\right)_{2}, \mathrm{Mg}\left(\mathrm{NO}_{3}\right)_{2}$ and $\mathrm{MgCl}_{2}[42,69,70]$. Thus, $t_{i}$ value in this work approves the PE to be used in the EDLC fabrication. 


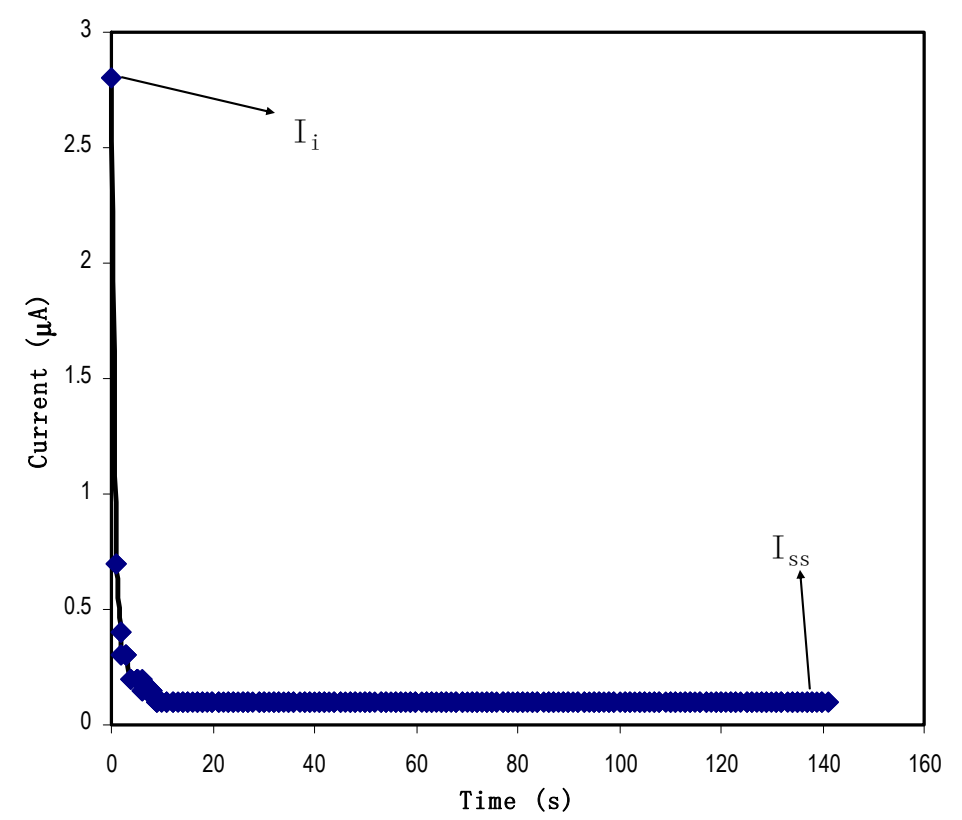

Figure 3. Polarization of the highest conducting electrolyte at $0.8 \mathrm{~V}$ working voltage.

\subsubsection{Linear Sweep Voltammetry (LSV) Study}

Linear sweep voltammetry (LSV) analysis was performed to study the potential stability of the $\mathrm{PE}$ by using a $20 \mathrm{mV} / \mathrm{s}$ scan rate. The potential stability of a PE is vital because, in energy storage devices, the rapid charge-discharge process can degrade the PE if the potential range is higher than the decomposition of the PE. LSV is a standard method used in the study of fuel cells, SCs, solar cells and batteries [71]. Figure 4 illustrates the current pattern as the potential is swept linear up to $3.5 \mathrm{~V}$. A sharp increase of current from 2 to $14 \mathrm{~mA} / \mathrm{cm}^{2}$ can be observed as the potential varies from 2.4 to $3.5 \mathrm{~V}$. The drastic increase in current values indicates the degradation process of the polymer [72]. As reported by Jo et al. [73], a magnesium perchlorate $\left(\mathrm{Mg}\left(\mathrm{ClO}_{4}\right)_{2}\right)$ system is electrochemically stable up to $2 \mathrm{~V}$. A film of PMMA-Mg( $\left(\mathrm{CF}_{3} \mathrm{SO}_{3}\right)_{2}$ is reported that can withstand potential up to $2.5 \mathrm{~V}$ [74]. Hence, it can be concluded that the highest conducting electrolyte in this work can be used as an electrodes separator in the fabrication of EDL.

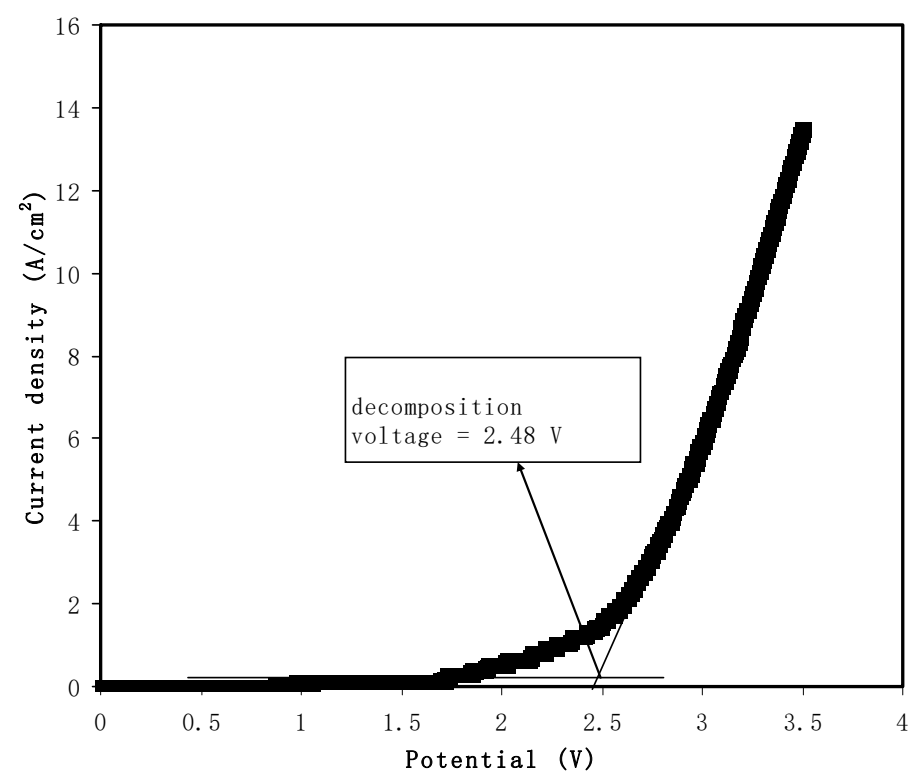

Figure 4. Linear sweep voltammetry (LSV) plot of the highest conducting electrolyte at $20 \mathrm{mV} / \mathrm{s}$. 


\subsubsection{Cyclic Voltammetry (CV) Studies of Fabricated EDLC}

The constructed EDLC with the arrangement of activated carbon/highest conducting samplelactivated carbon is analyzed using cyclic voltammetry (CV) analysis. Figure 5 shows CV plots with the absence of redox peaks. Peaks are usually shown in the CV plot of batteries or any energy devices requiring a chemical reaction with the electrode. Unlike batteries, ions undergo the adsorption/desorption process called non-Faradic [75]. CV shape for higher scan rate looks like a leaf, while at a lower scan rate the shape of the $\mathrm{CV}$ plot is more like a rectangular shape. One of the characteristics of a capacitor is that the $\mathrm{CV}$ response is scan rate dependent. At a large scan rate, the migration of ions occurs at a rapid rate.

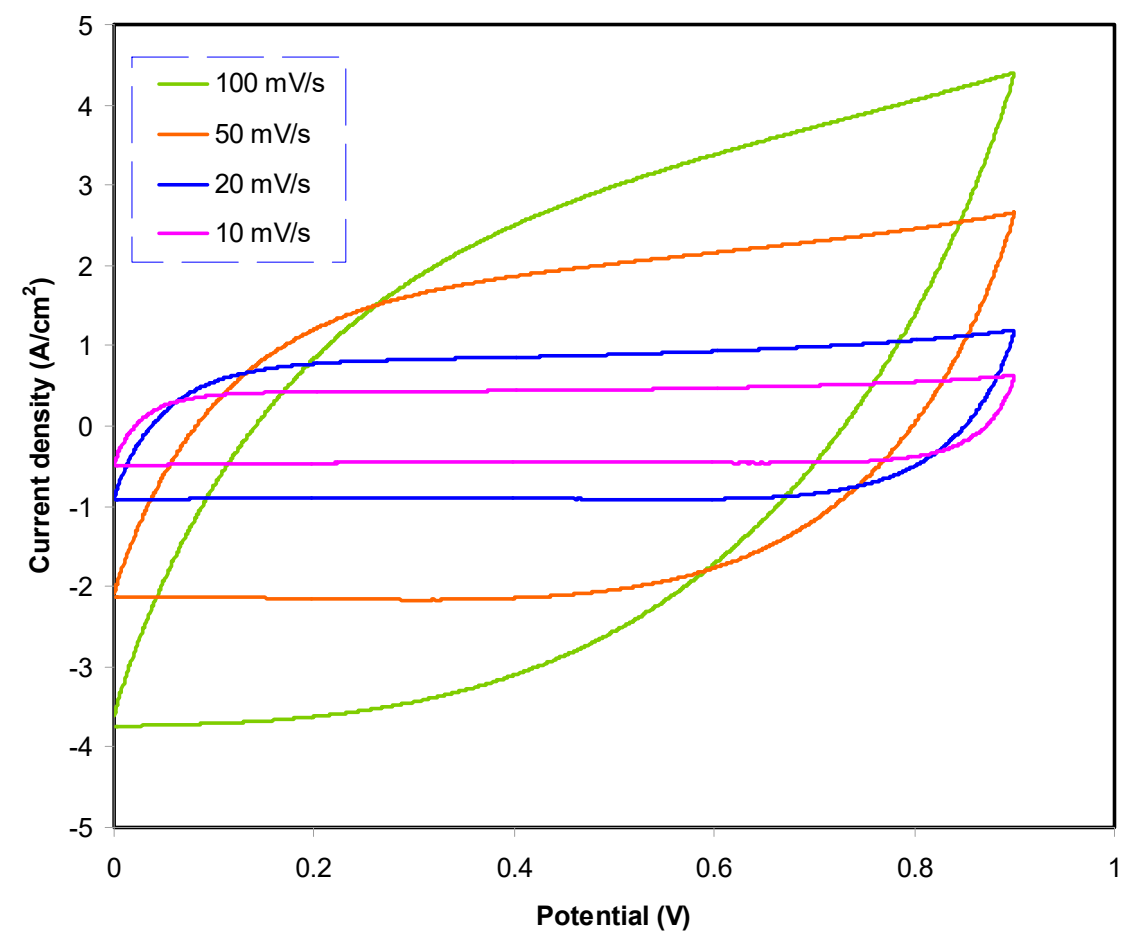

Figure 5. Cyclic voltammetry (CV) plot of the highest conducting electrolyte at various scan rates.

Furthermore, due to carbon porosity and internal resistance, current-voltage dependence is produced [76]. The obtained value of $C_{c v}$ is tabulated in Table 5 . At $100 \mathrm{mV} / \mathrm{s}, C_{c v}$ is $16.8 \mathrm{~F} / \mathrm{g}$ and $25.8 \mathrm{~F} / \mathrm{g}$ as the scan rate reduces to $50 \mathrm{mV} / \mathrm{s}$. $C_{c v}$ is observed to be highest at a low scan rate. These results show that, at a low scan rate, an almost perfect plateau region can be observed shown in Figure 5, which indicates that the charge carriers move at an almost slow and stable rate, thus developing ion accumulation at the electrode-electrolyte boundary with low ohmic resistance [77]. The reduction of $C_{c v}$ with increasing scan rate is related to the presence of internal resistance. The time scale of the current to reach a horizontal constant value on the reversal of the potential scan is increased at a high scan rate. The longer delay at the switching potential induces the electrical double-layers' slow reorganization due to the high resistance of ionic mobility in the micropores of activated carbon in the EDLC [78,79].

Table 5. Specific capacitance at various scan rates.

\begin{tabular}{cc}
\hline Scan Rate $(\mathbf{m V} / \mathbf{s})$ & $C_{c v}(\mathbf{F} / \mathbf{g})$ \\
\hline 100 & 16.8 \\
50 & 25.8 \\
20 & 32.6 \\
10 & 35.2 \\
\hline
\end{tabular}




\subsubsection{Charge-Discharge Study}

The typical charge-discharge plot of the EDLC is depicted in Figure 6. The constructed EDLC is subjected to a current density of $0.75 \mathrm{~mA} / \mathrm{cm}^{2}$ from 0 to $0.9 \mathrm{~V}$. The linearity of the slope indicates that the EDLC has the right capacitor energy storage mechanism [80]. Before the discharge process, it is noticeable that there is a slight sharp reduction in potential. This is due to several reasons, including electrolyte bulk resistance and the gap between the electrolyte and current collectors. The $V_{d}$ value for each cycle is plotted in Figure 7, where it is stable until the 120th cycle at an average of $0.125 \mathrm{~V}$. Beyond the 120th cycle, a fluctuated pattern of $V_{d}$ can be seen. Equation (6) can be used to calculate equivalence series resistance (ESR) as $V_{d}$ has been obtained. ESR values are tabulated in Table 6. The internal resistance of the EDLC is found to be $<90 \mathrm{Ohm}$. The small value of ESR means that the EDLC in this work has good electrode-electrolyte contact where it is easy for ions to move towards the activated carbon electrode surface [81].

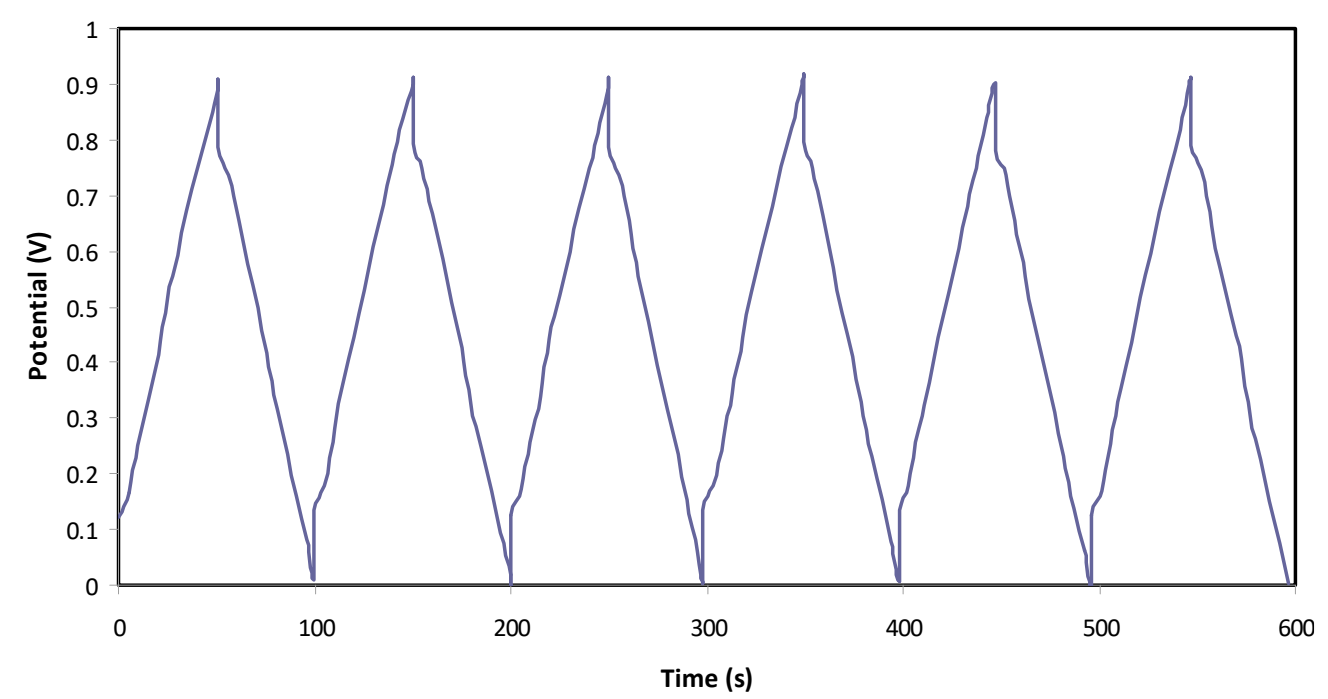

Figure 6. Charge-discharge plot of the electric double-layer capacitor (EDLC) at selected cycles.

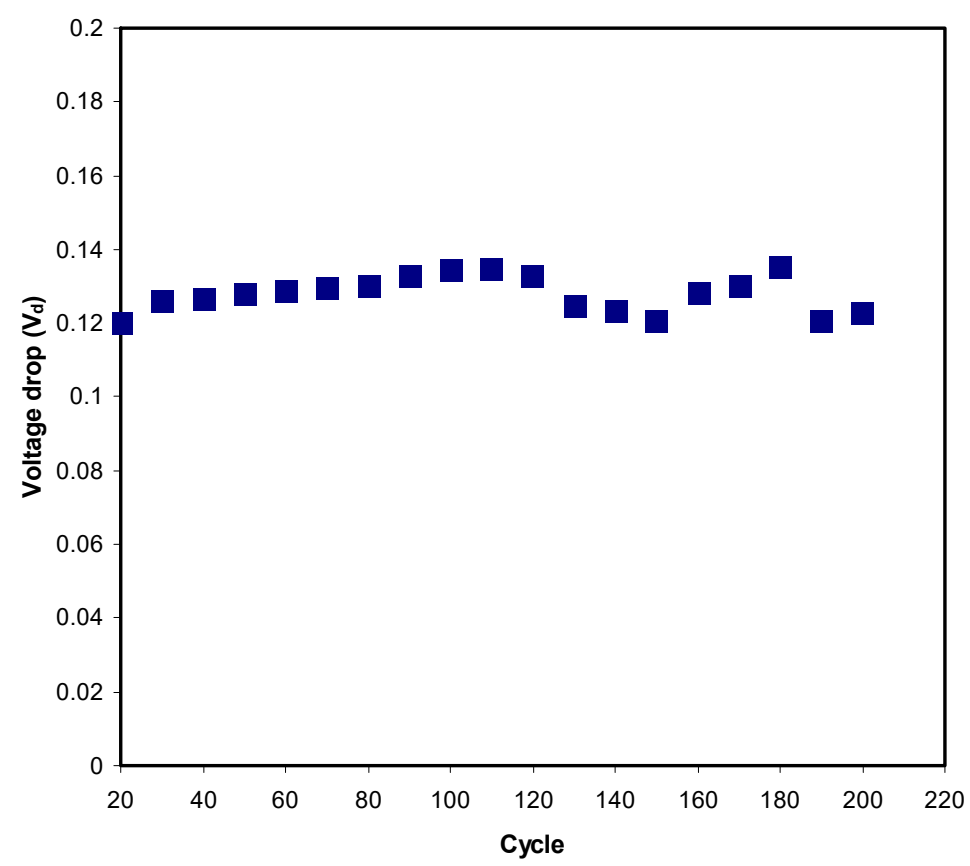

Figure 7. Voltage drop before discharge process for 200 cycles. 
Table 6. Internal resistance of the EDLC at selected cycles.

\begin{tabular}{cc}
\hline Cycle Number & ESR (Ohm) \\
\hline 1 & 75.7 \\
10 & 76.3 \\
30 & 83.9 \\
50 & 85.2 \\
70 & 86.7 \\
90 & 88.5 \\
110 & 89.9 \\
130 & 83.2 \\
150 & 80.3 \\
170 & 86.7 \\
200 & 81.9 \\
\hline
\end{tabular}

The value of $C_{c d}$ of the EDLC in this work is presented in Figure 8. A stable set of $C_{c d}$ is obtained with an average of $47.4 \mathrm{~F} / \mathrm{g}$ throughout 200 cycles. The large surface area of activated carbon $\left(2500 \mathrm{~m}^{2} / \mathrm{g}\right)$ allows charge carriers of $\mathrm{Mg}\left(\mathrm{CH}_{3} \mathrm{COO}\right)_{2}$ to develop a charge double-layer. Chong et al. [82] reported that the inclusion of silica nano-particles into hydroxyethyl cellulose- $\mathrm{Mg}\left(\mathrm{CF}_{3} \mathrm{SO}_{3}\right)_{2}$ provides $C_{c d}$ of 25.1 F/g. The PVdF-HFP-MgTF2-EMITf system-based EDLC shows a range of $C_{c d}$ from 31 to $41 \mathrm{~F} / \mathrm{g}$ [83]. The EDLC reported by Francis et al. [84] has a $C_{c d}$ value from 15 to $45 \mathrm{~F} / \mathrm{g}$ for PVA- $\mathrm{Mg}\left(\mathrm{CF}_{3} \mathrm{SO}_{3}\right)_{2}$ system. The efficiency of the EDLC is illustrated in Figure 8 . The efficiency of $72.5 \%$ can be seen in the 1 st cycle. Typically, at initial cycles, the charging process takes a longer time compared to discharging. As current is applied, charge carriers start to migrate towards the electrode and become familiar with the conduction pattern. This stage usually gives low efficiency. The efficiency is $96 \%$ at the 7 th cycle, where it is consistent until the 200th cycle at an average of $95 \%$. A large efficiency signifies that the time taken for charging and discharge is almost identical. This outcome indicates that the EDLC in this work has good cycling stability and contact and less charge loss of up to 400 cycles.

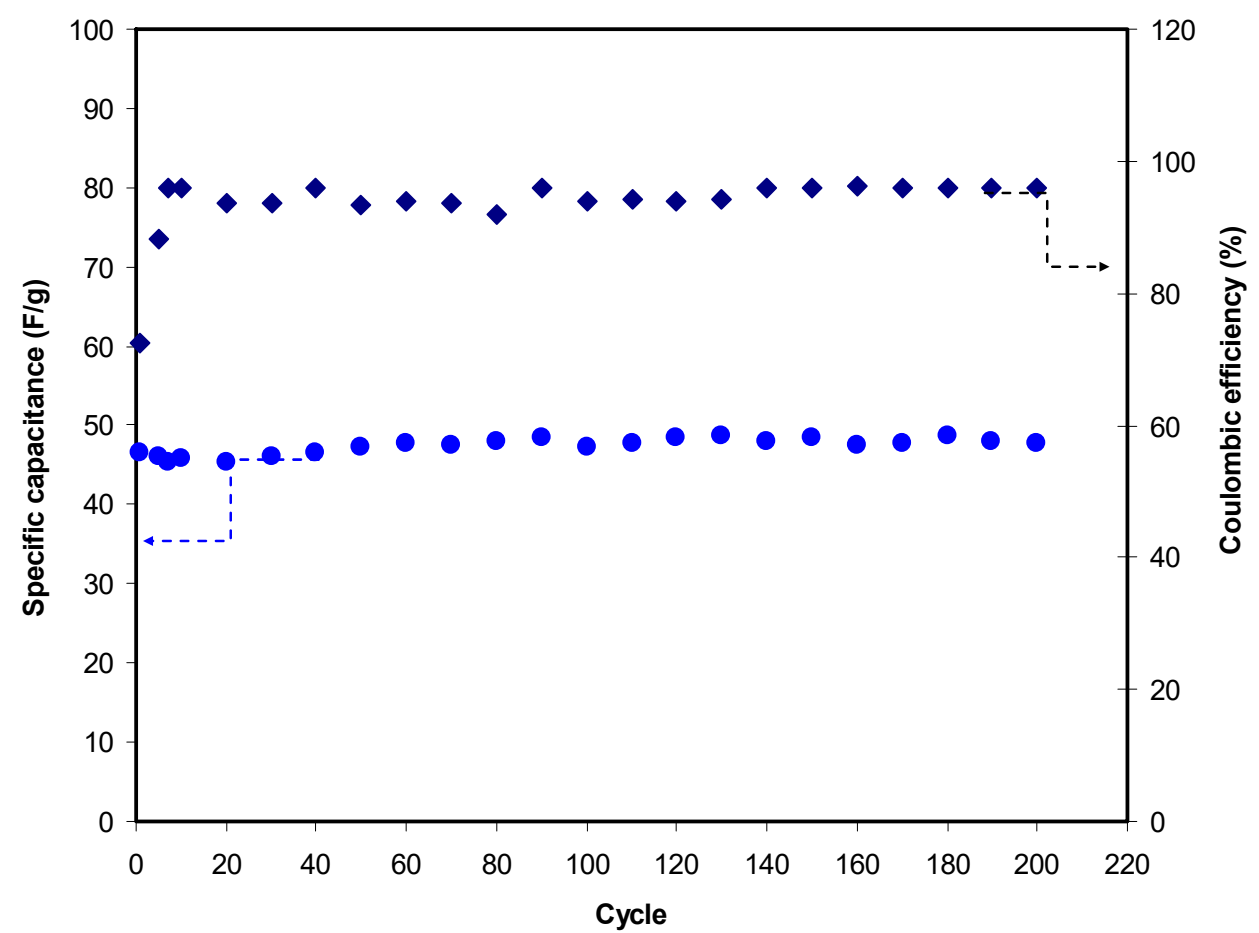

Figure 8. Specific capacitance and efficiency of the EDLC throughout the 200 cycles. 
Figure 9 shows the variation of $E$ and $P$ for 200 cycles. E value is observed to be stable at an average of $5.32 \mathrm{Wh} / \mathrm{kg}$ throughout the 200 charge-discharge cycles. This outcome indicates that anions $\left(\mathrm{CH}_{3} \mathrm{COO}^{-}\right)$and cations $\left(\mathrm{Mg}^{2+}\right)$ in the polymer chain of the CS-MC blend migrate toward the surface of the activated carbon electrode at an almost similar energy barrier [85]. By referring to Equation (7), energy density is directly proportional to specific capacitance; thus, $E$ is expected to have a similar Ccd $\operatorname{tren}_{d}$. As reported by Bandaranayake et al. [86], a $\mathrm{MgCl}_{2}$-based EDLC provides $\mathrm{E}$ of $5 \mathrm{Wh} / \mathrm{kg}$. Winie et al. [87] reported that a CS-based EDLC has energy density from 0.57 to $2.8 \mathrm{Wh} / \mathrm{kg}$ as the current density varies from 2 to $0.6 \mathrm{~mA} / \mathrm{cm}^{2}$, respectively. A constant capacitance and energy density trend indicates that the number of ions aggregate formation is low. The EDLC has a higher power density than batteries due to the absence of the intercalation/deintercalation process in an EDLC. $P$ of the EDLC in this work is also illustrated in Figure 9. $P$-value at the 1st cycle is $1338.5 \mathrm{~W} / \mathrm{kg}$ and it drops to 1206.3 $\mathrm{W} / \mathrm{kg}$ at the 30th cycle. According to work by Yassine et al. [88], power density is related to the internal resistance. The reduction of $P$ is due to an increase in ESR value. Beyond the 40th cycle, the $P$ pattern becomes more stable with a small fluctuation in the range of 1217 to $1261 \mathrm{~W} / \mathrm{kg}$. Bandaranayake et al. [86] reported a $P$ of $341 \mathrm{~W} / \mathrm{kg}$.

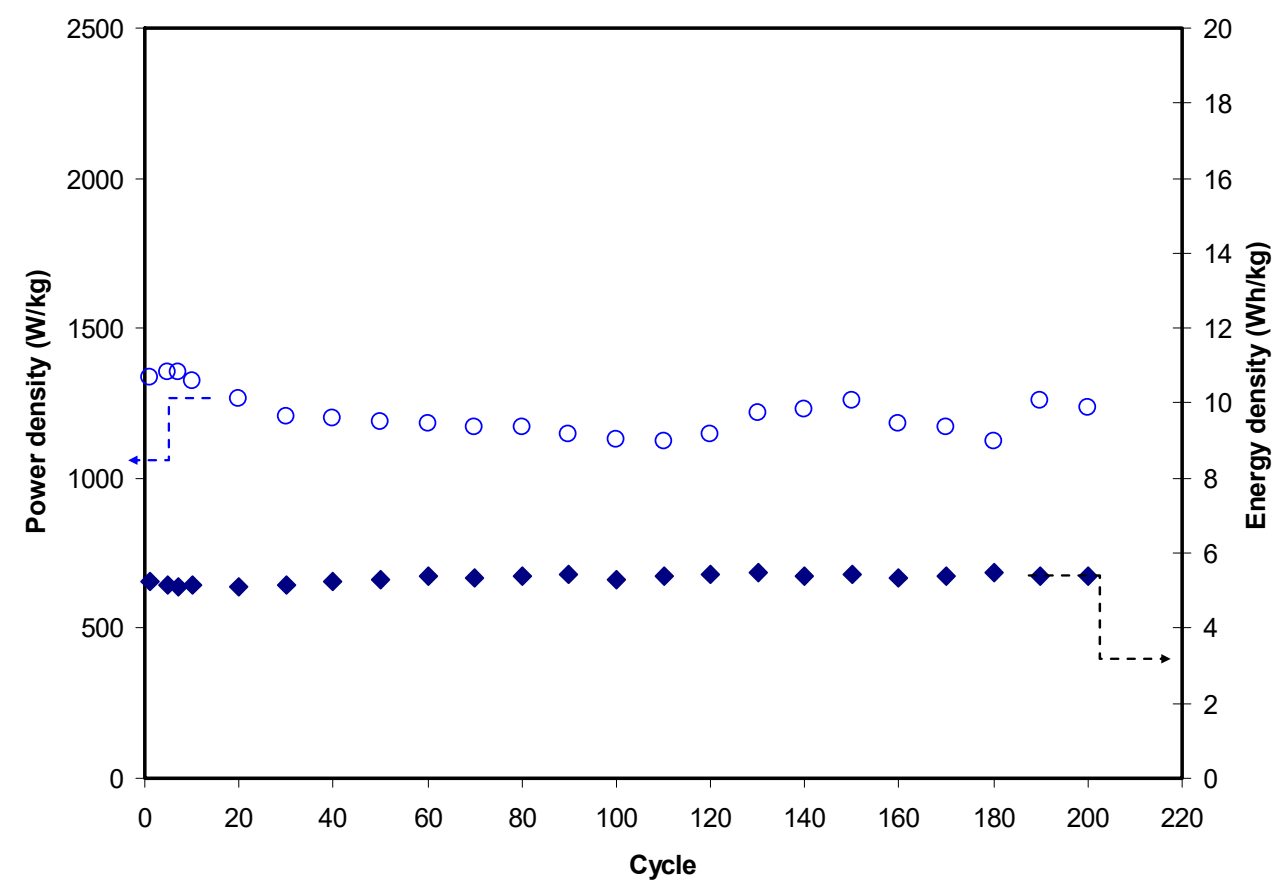

Figure 9. Energy and power density of the EDLC throughout the 200 cycles.

\section{Conclusions}

CS:MC: $\mathrm{Mg}\left(\mathrm{CH}_{3} \mathrm{COO}\right)_{2}$ : $\mathrm{Ni}(\mathrm{II})$-complex:glycerol based electrolytes were successfully synthesized via a solution-casting method. Chitosan was blended with methylcellulose for the host polymer, while ions were provided by magnesium acetate $\left(\mathrm{Mg}\left(\mathrm{CH}_{3} \mathrm{COO}\right)_{2}\right)$. $\mathrm{Ni}(\mathrm{II})$-complex was added to improve the amorphous phase, while glycerol was used to improve ionic dissociation. The addition of $42 \mathrm{wt} \%$ glycerol maximized the conductivity to $1.02 \times 10^{-4} \mathrm{~S} \mathrm{~cm}^{-1}$. The XRD results indicated that the maximum conducting plasticized electrolyte has the minimum crystallinity degree determined to be 2.08 . The XRD outcomes can also be associated with the trend in the degree of crystallinity with the change in the electrolytes' conductivity. It was identified that ions in CS:MC: $\mathrm{Mg}\left(\mathrm{CH}_{3} \mathrm{COO}\right)_{2}: \mathrm{Ni}(\mathrm{II})$-complex:glycerol were the dominant charge carrier as $t_{i}>t_{e}$. The electrolyte in this work can withstand applied potential up to $2.48 \mathrm{~V}$; thus, the electrolyte was useful for EDLC applications. Capacitive characteristics in the assembled EDLC were verified by cyclic voltammetry, as no redox current was produced. Specific capacitance was found to reduce with increasing scan rate. Important parameters of the EDLC were 
stable up to 200 cycles. Energy density, specific capacitance and power density were $5.32 \mathrm{Wh} / \mathrm{kg}$, 47.4 $\mathrm{F} / \mathrm{g}$ and $1338.5 \mathrm{~W} / \mathrm{kg}$, respectively. Good cyclability of the EDLC was achieved as the value of efficiency was $\sim 95 \%$.

Author Contributions: Conceptualization, E.M.A.D., S.B.A., M.M.N. and M.F.Z.K.; Formal analysis, M.A.B., A.S.F.M.A. and H.J.W.; Investigation, M.H.H.; Methodology, M.H.H.; Project administration, S.B.A., M.M.N., Y.M.Y. and M.F.Z.K.; Supervision, S.B.A.; Validation, S.A.-Z.; Writing—original draft, S.B.A.; Writing-review and editing, E.M.A.D., M.A.B., M.M.N., A.S.F.M.A., Y.M.Y., S.A.-Z., M.F.Z.K. and H.J.W. All authors have read and agreed to the published version of the manuscript.

Funding: This research received no external funding.

Acknowledgments: The authors appreciatively acknowledge the support from the University of Sulaimani, University of Malaya, Prince Sultan University, and Komar University of Science and Technology.

Conflicts of Interest: The authors declare no conflict of interest.

\section{References}

1. Jia, P.; Ouyang, R.; Cao, P.; Tong, X.; Zhou, X.; Lei, T.; Zhao, Y.; Guo, N.; Chang, H.; Miao, Y.; et al. Review: Recent advances and future development of metal complexes as anticancer agents. J. Coord. Chem. 2017, 70, 2175-2201. [CrossRef]

2. Aziz, S.B.; Brza, M.A.; Nofal, M.M.; Abdulwahid, R.T.; Hussen, S.A.; Hussein, A.M.; Karim, W.O. A Comprehensive Review on Optical Properties of Polymer Electrolytes and Composites. Materials 2020, 13, 3675. [CrossRef]

3. Brza, M.A.; Aziz, S.B.; Anuar, H.; Structural, F.A. ion transport parameter and electrochemical properties of plasticized polymer composite electrolyte based on PVA: A novel approach to fabricate high performance EDLC devices. Polym. Test. 2020, 91, 106813. [CrossRef]

4. Ndagi, U.; Mhlongo, N.; Soliman, M.E. Metal complexes in cancer therapy-An update from drug design perspective. Drug Des. Devel. Ther. 2017, 11, 599-616. [CrossRef]

5. Brza, M.A.; Aziz, S.B.; Anuar, H.; Al Hazza, M.H.F. From Green Remediation to Polymer Hybrid Fabrication with Improved Optical Band Gaps. Int. J. Mol. Sci. 2019, 20, 3910. [CrossRef]

6. Asnawi, A.S.F.M.; Aziz, S.B.; Nofal, M.M.; Yusof, Y.M.; Brevik, I.; Hamsan, M.H.; Brza, M.A.; Abdulwahid, R.T.; Kadir, M.F.Z. Metal Complex as a Novel Approach to Enhance the Amorphous Phase and Improve the EDLC Performance of Plasticized Proton Conducting Chitosan-Based Polymer Electrolyte. Membranes 2020, 10, 132. [CrossRef]

7. Hamsan, M.H.; Aziz, S.B.; Shukur, M.F.; Kadir, M.F.Z. Protonic cell performance employing electrolytes based on plasticized methylcellulose-potato starch- $\mathrm{NH}_{4} \mathrm{NO}_{3}$. Ionics 2019, 25, 559-572. [CrossRef]

8. Stepniak, I.; Galinski, M.; Nowacki, K.; Wysokowski, M.; Jakubowska, P.; Bazhenov, V.V.; Leisegang, T.; Ehrlich, H.; Jesionowski, T. A novel chitosan/sponge chitin origin material as a membrane for supercapacitors-preparation and characterization. RSC Adv. 2016, 6, 4007-4013. [CrossRef]

9. Piana, G.; Ricciardi, M.; Bella, F.; Cucciniello, R.; Proto, A.; Gerbaldi, C. Poly(glycidyl ether)s recycling from industrial waste and feasibility study of reuse as electrolytes in sodium-based batteries. Chem. Eng. J. 2020, 382, 122934. [CrossRef]

10. Piana, G.; Bella, F.; Geobaldo, F.; Meligrana, G.; Gerbaldi, C. PEO/LAGP hybrid solid polymer electrolytes for ambient temperature lithium batteries by solvent-free, "one pot" preparation. J. Energy Storage 2019, 26, 100947. [CrossRef]

11. Falco, M.; Castro, L.; Nair, J.R.; Bella, F.; Bardé, F.; Meligrana, G.; Gerbaldi, C. UV-Cross-Linked Composite Polymer Electrolyte for High-Rate, Ambient Temperature Lithium Batteries. ACS Appl. Energy Mater. 2019, 2, 1600-1607. [CrossRef]

12. Falco, M.; Simari, C.; Ferrara, C.; Nair, J.R.; Meligrana, G.; Bella, F.; Nicotera, I.; Mustarelli, P.; Winter, M.; Gerbaldi, C. Understanding the effect of UV-induced cross-linking on the physicochemical properties of highly performing PEO/LiTFSI-based polymer electrolytes. Langmuir 2019, 35, 8210-8219. [CrossRef] [PubMed]

13. Nair, J.R.; Colò, F.; Kazzazi, A.; Moreno, M.; Bresser, D.; Lin, R.; Bella, F.; Meligrana, G.; Fantini, S.; Simonetti, E.; et al. Room temperature ionic liquid (RTIL)-based electrolyte cocktails for safe, high working potential Li-based polymer batteries. J. Power Sources 2019, 412, 398-407. [CrossRef] 
14. Mauger, A.; Julien, C.; Paolella, A.; Armand, M.; Zaghib, K. A comprehensive review of lithium salts and beyond for rechargeable batteries: Progress and perspectives. Mater. Sci. Eng. R Reports 2018, 134, 1-21. [CrossRef]

15. Mauger, A.; Julien, C.M.; Paolella, A.; Armand, M.; Zaghib, K. Recent progress on organic electrodes materials for rechargeable batteries and supercapacitors. Materials 2019, 12, 1770. [CrossRef] [PubMed]

16. Mauger, A.; Julien, C.M.; Paolella, A.; Armand, M.; Zaghib, K. Building better batteries in the solid state: A review. Materials 2019, 12, 3892. [CrossRef]

17. Zhou, D.; Fan, L.-Z.; Yang, J.; Fan, L.-Z. Flexible solid-state self-charging supercapacitor based on symmetric electrodes and piezo-electrolyte. Chem. Eng. J. 2021, 406, 126825. [CrossRef]

18. Bhat, V.S.; Kanagavalli, P.; Sriram, G.; John, N.S.; Veerapandian, M.; Kurkuri, M.; Hegde, G. Low cost, catalyst free, high performance supercapacitors based on porous nano carbon derived from agriculture waste. J. Energy Storage 2020, 32, 101829. [CrossRef]

19. Scalia, A.; Bella, F.; Lamberti, A.; Gerbaldi, C.; Tresso, E. Innovative multipolymer electrolyte membrane designed by oxygen inhibited UV-crosslinking e,nables solid-state in plane integration of energy conversion and storage devices. Energy 2019, 166, 789-795. [CrossRef]

20. Aziz, S.B.; Brza, M.; Hamsan, M.; Kadir, M.; Muzakir, S.; Abdulwahid, R.T. Effect of ohmic-drop on electrochemical performance of EDLC fabricated from PVA: Dextran: NH4I based polymer blend electrolytes. J. Mater. Res. Technol. 2020, 9, 3734-3745. [CrossRef]

21. Aziz, S.B.; Hamsan, M.; Brza, M.; Kadir, M.; Muzakir, S.; Abdulwahid, R.T. Effect of glycerol on EDLC characteristics of chitosan: Methylcellulose polymer blend electrolytes. J. Mater. Res. Technol. 2020, 9, 8355-8366. [CrossRef]

22. Aziz, S.B.; Hamsan, M.H.; Nofal, M.M.; Karim, W.O.; Brevik, I.; Brza, M.A.; Abdulwahid, R.T.; Al-Zangana, S.; Kadir, M.F.Z. Structural, Impedance and Electrochemical Characteristics of Electrical Double Layer Capacitor Devices Based on Chitosan: Dextran Biopolymer Blend Electrolytes. Polymers 2020, 12, 1411. [CrossRef] [PubMed]

23. Asnawi, A.S.F.M.; Aziz, S.B.; Nofal, M.M.; Hamsan, M.H.; Brza, M.A.; Yusof, Y.M.; Abdulwahid, R.T.; Muzakir, S.K.; Kadir, M.F.Z. Glycerolized $\mathrm{Li}^{+}$ion conducting chitosan-based polymer electrolyte for energy storage EDLC device applications with relatively high energy density. Polymers 2020, 12, 1433. [CrossRef] [PubMed]

24. Aziz, S.B.; Hamsan, M.H.H.; Nofal, M.M.M.; San, S.; Abdulwahid, R.T.; Saeed, S.R.R.; Brza, M.A.; Kadir, M.F.Z.; Mohammed, S.J.; Al-Zangana, S. Al-Zangana. From Cellulose, Shrimp and Crab Shells to Energy Storage EDLC Cells: The Study of Structural and Electrochemical Properties of Proton Conducting Chitosan-Based Biopolymer Blend Electrolytes. Polymers 2020, 12, 1526. [CrossRef]

25. Hassan, M.F.; Azimi, N.S.N.; Kamarudin, K.H.; Sheng, C.K. Solid polymer electrolytes based on starch-Magnesium Sulphate: Study on morphology and electrical conductivity. ASM Sci. J. 2018, 11, 17-28.

26. Sudhakar, Y.N.; Selvakumar, M.; Bhat, D.K. Preparation and characterization of phosphoric acid-doped hydroxyethyl cellulose electrolyte for use in supercapacitor. Mater. Renew. Sustain. Energy 2015, 4, 1-9. [CrossRef]

27. Moniha, V.; Alagar, M.; Selvasekarapandian, S.; Sundaresan, B.; Hemalatha, R.; Boopathi, G. Synthesis and characterization of bio-polymer electrolyte based on iota-carrageenan with ammonium thiocyanate and its applications. J. Solid State Electrochem. 2018, 22, 3209-3223. [CrossRef]

28. Thakur, V.K.; Thakur, M.K. Recent advances in graft copolymerization and applications of chitosan: A review. ACS Sustain. Chem. Eng. 2014, 2, 2637-2652. [CrossRef]

29. Du, B.W.; Hu, S.Y.; Singh, R.; Tsai, T.T.; Lin, C.C.; Ko, F.H. Eco-friendly and biodegradable biopolymer chitosan $/ \mathrm{Y}_{2} \mathrm{O}_{3}$ composite materials in flexible organic thin-film transistors. Materials 2017, 10, 1026.

30. Taghizadeh, M.T.; Seifi-Aghjekohal, P. Sonocatalytic degradation of 2-hydroxyethyl cellulose in the presence of some nanoparticles. Ultrason. Sonochem. 2015, 26, 265-272. [CrossRef]

31. Iro, Z.S.; Subramani, C.; Dash, S.S. A brief review on electrode materials for supercapacitor. Int. J. Electrochem. Sci. 2016, 11, 10628-10643. [CrossRef]

32. Shukur, M.F.; Ithnin, R.; Illias, H.A.; Kadir, M.F.Z. Proton conducting polymer electrolyte based on plasticized chitosan-PEO blend and application in electrochemical devices. Opt. Mater. 2013, 35, 1834-1841. [CrossRef] 
33. Ling, L.; Qing-Han, M. Electrochemical properties of mesoporous carbon aerogel electrodes for electric double layer capacitors. J. Mater. Sci. 2005, 40, 4105-4107. [CrossRef]

34. Subramanian, V.; Zhu, H.; Wei, B. Nanostructured manganese oxides and their composites with carbon nanotubes as electrode materials for energy storage devices. Pure Appl. Chem. 2008, 80, 2327-2343. [CrossRef]

35. Kadir, M.F.Z.; Majid, S.R.; Arof, A.K. Plasticized chitosan-PVA blend polymer electrolyte based proton battery. Electrochim. Acta 2010, 55, 1475-1482. [CrossRef]

36. Wang, H.; Lin, J.; Shen, Z.X. Polyaniline (PANi) based electrode materials for energy storage and conversion. J. Sci. Adv. Mater. Devices 2016, 1, 225-255. [CrossRef]

37. Inagaki, M.; Konno, H.; Tanaike, O. Carbon materials for electrochemical capacitors. J. Power Sources 2010, 195, 7880-7903. [CrossRef]

38. Zhang, D.; Zhang, X.; Chen, Y.; Yu, P.; Wang, C.; Ma, Y. Enhanced capacitance and rate capability of graphene/polypyrrole composite as electrode material for supercapacitors. J. Power Sources 2011, 196, 5990-5996. [CrossRef]

39. Pell, W.G.; Conway, B.E. Peculiarities and requirements of asymmetric capacitor devices based on combination of capacitor and battery-type electrodes. J. Power Sources 2004, 136, 334-345. [CrossRef]

40. Song, J.; Sahadeo, E.; Noked, M.; Lee, S.B. Mapping the challenges of magnesium battery. J. Phys. Chem. Lett. 2016, 7, 1736-1749. [CrossRef]

41. Crowther, O.; West, A.C. Effect of electrolyte composition on lithium dendrite growth. J. Electrochem. Soc. 2008, 155, A806. [CrossRef]

42. Polu, A.R.; Kumar, R. Ionic Conductivity and Discharge Characteristic Studies of PVA-Mg(CH$\left.{ }_{3} \mathrm{COO}\right) 2$ Solid Polymer Electrolytes. Int. J. Polym. Mater. 2020, 62, 76-80. [CrossRef]

43. Hassan, M.F.; Azimi, N.S.N. Conductivity and transport properties of starch/glycerin-MgSO 4 solid polymer electrolytes. Int. J. Adv. Appl. Sci. 2019, 6, 38-43. [CrossRef]

44. Aziz, S.B. Role of dielectric constant on ion transport: Reformulated Arrhenius equation. Adv. Mater. Sci. Eng. 2016, 2016, 2527013. [CrossRef]

45. Wan, Y.; Creber, K.A.M.; Peppley, B.; Bui, V.T. Synthesis, characterization and ionic conductive properties of phosphorylated chitosan membranes. Macromol. Chem. Phys. 2003, 204, 850-858. [CrossRef]

46. Brza, M.A.; Aziz, S.B.; Anuar, H.; Dannoun, E.M.A.; Ali, F.B.; Abdulwahid, R.T.; Al-Zangana, S.; Kadir, M.F.Z. The study of EDLC device with high electrochemical performance fabricated from proton ion conducting PVA-based polymer composite electrolytes plasticized with glycerol. Polymers 2020, 12, 1896. [CrossRef]

47. Aziz, S.B.; Abidin, Z.H.Z.; Kadir, M.F.Z. Innovative method to avoid the reduction of silver ions to silver nanoparticles in silver ion conducting based polymer electrolytes. Phys. Scr. 2015, 90, 035808. [CrossRef]

48. Liebeck, B.M.; Hidalgo, N.; Roth, G.; Popescu, C.; Böker, A. Synthesis and Characterization of Methyl Cellulose/Keratin Hydrolysate Composite Membranes. Polymers 2017, 9, 91. [CrossRef] [PubMed]

49. Liu, P.; Xiangmei, W.; Zhong, L. Miscibility Study of Chitosan and Methylcellulose Blends. Adv. Mater. Res. 2013, 750-752, 802-805. [CrossRef]

50. Aziz, N.A.N.; Idris, N.K.; Isa, M.I.N. Solid Polymer Electrolytes Based on Methylcellulose: FT-IR and Ionic Conductivity Studies. Int. J. Polym. Anal. Charact. 2010, 15, 319-327. [CrossRef]

51. Aziz, S.B.; Rasheed, M.A.; Ahmed, H.M. Synthesis of Polymer Nanocomposites Based on [Methyl Cellulose](1 - x):(CuS) $\times(0.02 \mathrm{M} \leq \mathrm{x} \leq 0.08 \mathrm{M})$ with Desired Optical Band Gaps. Polymers(Basel) 2017, 9, 194. [CrossRef] [PubMed]

52. Aziz, S.B.; Abidin, Z.; Arof, A. Effect of silver nanoparticles on the DC conductivity in chitosan-silver triflate polymer electrolyte. Phys. B 2010, 405, 4429-4433. [CrossRef]

53. Aziz, S.B.; Abdullah, R.M. Crystalline and amorphous phase identification from the tan $\delta$ relaxation peaks and impedance plots in polymer blend electrolytes based on [CS: AgNt]x:PEO (x-1)(10 $\leq \mathrm{x} \leq 50)$. Electrochim. Acta 2018, 285, 30-46. [CrossRef]

54. Salleh, N.S.; Aziz, S.B.; Aspanut, Z.; Kadir, M.F.Z. Electrical impedance and conduction mechanism analysis of biopolymer electrolytes based on methyl cellulose doped with ammonium iodide. Ionics 2016, 22, 2157. [CrossRef]

55. Brza, M.A.; Hamsan, H.M.; Kadir, M.F.Z.; Abdulwahid, R.T. Electrochemical characteristics of solid state double-layer capacitor constructed from proton conducting chitosan-based polymer blend electrolytes. Polym. Bull. 2020. [CrossRef] 
56. Reddy, M.J.; Chu, P.P. Ion pair formation and its effect in PEO:Mg solid polymer electrolyte system. J. Power Sources 2002, 109, 340-346. [CrossRef]

57. Hamsan, M.; Aziz, S.B.; Nofal, M.M.; Brza, M.; Abdulwahid, R.T.; Hadi, J.M.; Karim, W.O.; Kadir, M. Characteristics of EDLC device fabricated from plasticized chitosan: $\mathrm{MgCl}_{2}$ based polymer electrolyte. $J$. Mater. Res. Technol. 2020, 9, 10635-10646. [CrossRef]

58. Cho, S.; Chen, C.-F.; Mukherjee, P.P. Influence of Microstructure on Impedance Response in Intercalation Electrodes. J. Electrochem. Soc. 2015, 162, A1202-A1214. [CrossRef]

59. Woo, T.J.; Kadir, M.F.Z.; Ahmed, H.M. A conceptual review on polymer electrolytes and ion transport models. J. Sci. Adv. Mater. Devices 2018, 3, 1-17.

60. Svensson, A.M.; Valøen, L.O.; Tunold, R. Modeling of the impedance response of porous metal hydride electrodes. Electrochim. Acta 2005, 50, 2647-2653. [CrossRef]

61. Aziz, S.B.; Abdullah, R.M.; Kadir, M.F.Z.; Ahmed, H.M. Non suitability of silver ion conducting polymer electrolytes based on chitosan mediated by barium titanate $\left(\mathrm{BaTiO}_{3}\right)$ for electrochemical device applications. Electrochim. Acta 2008, 296, 494-507. [CrossRef]

62. Aziz, S.B.; Abidin, Z.H.Z.; Arof, A.K. Influence of silver ion reduction on electrical modulus parameters of solid polymer electrolyte based on chitosan-silver triflate electrolyte membrane. Express Polym. Lett. 2010, 4, 300-310. [CrossRef]

63. Pradhan, D.K.; Samantaray, B.K.; Choudhary, R.N.P.; Karan, N.K.; Thomas, R.; Katiyar, R. Effect of plasticizer on structural and electrical properties of nanocomposite solid polymer electrolytes. Ionics 2011, 17, 127-134. [CrossRef]

64. Hamsan, M.H.; Shukur, M.F.; Kadir, M.F.Z. $\mathrm{NH}_{4} \mathrm{NO}_{3}$ as charge carrier contributor in glycerolized potato starch-methyl cellulose blend-based polymer electrolyte and the application in electrochemical double-layer capacitor. Ionics 2017, 23, 3429-3453. [CrossRef]

65. Aziz, S.B.; Hamsan, M.; Brza, M.; Kadir, M.; Abdulwahid, R.T.; Ghareeb, H.O.; Woo, H. Fabrication of energy storage EDLC device based on CS:PEO polymer blend electrolytes with high $\mathrm{Li}+$ ion transference number. Results Phys. 2019, 15, 102584. [CrossRef]

66. Brza, M.A.; Aziz, S.B.; Anuar, H.; Ali, F.; Hamsan, M.H.; Kadir, M.F.Z.; Abdulwahid, R.T. Metal framework as a novel approach for the fabrication of electric double layer capacitor device with high energy density using plasticized Poly(vinylalcohol): Ammonium thiocyanate based polymerelectrolyte. Arab J. Chem. 2020, 137247-137263. [CrossRef]

67. Aziz, S.B.; Hamsan, M.H.; Abdullah, R.M.; Kadir, M.F.Z. A Promising Polymer Blend Electrolytes Based on Chitosan: Methyl Cellulose for EDLC Application with High Specific Capacitance and Energy Density. Molecules 2019, 24, 2503. [CrossRef]

68. Amudha, S.; Suthanthiraraj, S.A. Silver ion conducting characteristics of a polyethylene oxide-based composite polymer electrolyte and application in solid state batteries. Adv. Mater. Lett. 2015, 6, 874-882. [CrossRef]

69. Priya, S.S.; Karthika, M.; Selvasekarapandian, S.; Manjuladevi, R. Preparation and characterization of polymer electrolyte based on biopolymer I-Carrageenan with magnesium nitrate. Solid State Ionics 2018, 327, $136-149$. [CrossRef]

70. Ponraj, T.; Ramalingam, A.; Selvasekarapandian, S.; Srikumar, S.R.; Manjuladevi, R. Plasticized solid polymer electrolyte based on triblock copolymer poly(vinylidene chloride-co-acrylonitrile-co-methyl methacrylate) for magnesium ion batteries. Polym. Bull. 2020, 1-23. [CrossRef]

71. Mokhtar, M.; Majlan, E.H.; Ahmad, A.; Tasirin, S.M.; Daud, W.R.W. Effect of ZnO filler on PVA-alkaline solid polymer electrolyte for aluminum-air battery applications. J. Electrochem. Soc. 2018, 165, A2483-A2492. [CrossRef]

72. Monisha, S.; Mathavan, T.; Selvasekarapandian, S.; Benial, A.M.; Latha, M.P. Preparation and characterization of cellulose acetate and lithium nitrate for advanced electrochemical devices. Ionics 2016, 23, 2697-2706. [CrossRef]

73. Jo, N.J.; Kim, N.Y.; Kang, S.Y.; Ryu, K.S. The influence of the cations of salts on the electrochemical stability of a solid polymer electrolyte based on segmented poly(ether urethane). Phys. Scr. 2010, T139, 014035. [CrossRef] 
74. Zainol, N.H.; Halizan, M.; Zharfan, M.; Chong, W.G.; Osman, Z. Ionic Transport and Electrochemical Properties of PMMA-Based Gel Polymer Electrolytes for Magnesium Batteries. Adv. Mater. Res. 2014, 1024, 348-351. [CrossRef]

75. Fattah, N.; Ng, H.; Mahipal, Y.; Numan, A.; Ramesh, S.; Ramesh, K. An approach to solid-state electrical double layer capacitors fabricated with graphene oxide-doped, ionic liquid-based solid copolymer electrolytes. Materials 2016, 9, 450. [CrossRef]

76. Jäckel, N.; Rodner, M.; Schreiber, A.; Jeongwook, J.; Zeiger, M.; Aslan, M.; Weingarth, D.; Presser, V. Anomalous or regular capacitance? The influence of pore size dispersity on double-layer formation. J. Power Sources 2016, 326, 660-671. [CrossRef]

77. Liew, C.W.; Ramesh, S.; Arof, A.K. Enhanced capacitance of EDLCs (electrical double layer capacitors) based on ionic liquid-added polymer electrolytes. Energy 2016, 109, 546-556. [CrossRef]

78. He, X.; Lei, J.; Geng, Y.; Zhang, X.; Wu, M.; Zheng, M. Preparation of microporous activated carbon and its electrochemical performance for electric double layer capacitor. J. Phys. Chem. Solids 2009, 70, 738-744. [CrossRef]

79. Fang, B.; Binder, L. A novel carbon electrode material for highly improved EDLC performance. J. Phys. Chem. B 2006, 110, 7877-7882. [CrossRef]

80. Eftekhari, A. The mechanism of ultrafast supercapacitors. J. Mater. Chem. A 2018, 6, 2866-2876. [CrossRef]

81. Asmara, S.N.; Kufian, M.Z.; Majid, S.R.; Arof, A.K. Preparation and characterization of magnesium ion gel polymer electrolytes for application in electrical double layer capacitors. Electrochim. Acta 2011, 57, 91-97. [CrossRef]

82. Chong, M.Y.; Numan, A.; Liew, C.-W.; Ng, H.M.; Ramesh, K.; Ramesh, S. Enhancing the performance of green solid-state electric double-layer capacitor incorporated with fumed silica nanoparticles. J. Phys. Chem. Solids 2018, 117, 194-203. [CrossRef]

83. Pandey, G.P.; Kumar, Y.; Hashmi, S.A. Ionic liquid incorporated polymer electrolytes for supercapacitor application. Indian J. Chem. Sect. A 2010, 49A, 743-751.

84. Francis, K.A.; Liew, C.-W.; Singh, R.; Ramesh, K. Ionic liquid enhanced magnesium-based polymer electrolytes for electrical double-layer capacitors. Ionics 2016, 22, 919-925. [CrossRef]

85. Shukur, M.F. Characterization of Ion Conducting Solid Biopolymer Electrolytes Based on Starch-chitosan Blend and Application in Electrochemical Devices. Ph.D. Thesis, University of Malaya, Kuala Lumpur, Malaysia, 2015.

86. Bandaranayake, C.; Yayathilake, Y.; Perera, K.; Vidanapathirana, K.; Bandara, L. Investigation of a gel polymer electrolyte based on polyacrylonitrile and magnesium chloride for a redox capacitor. Ceylon J. Sci. 2016, 45, 75-82. [CrossRef]

87. Winie, T.; Jamal, A.; Saaid, F.I.; Tseng, T.-Y. Hexanoyl chitosan/ENR25 blend polymer electrolyte system for electrical double layer capacitor. Polym Adv Technol. 2018, 30, 1-10. [CrossRef]

88. Yassine, M.; Fabris, D. Performance of Commercially Available Supercapacitors. Energies 2017, $10,1340$. [CrossRef]

Publisher's Note: MDPI stays neutral with regard to jurisdictional claims in published maps and institutional affiliations.

(C) 2020 by the authors. Licensee MDPI, Basel, Switzerland. This article is an open access article distributed under the terms and conditions of the Creative Commons Attribution (CC BY) license (http://creativecommons.org/licenses/by/4.0/). 